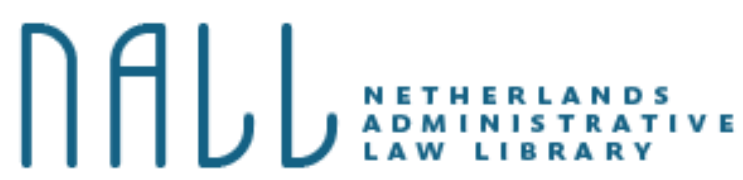

Citeerwijze van dit artikel:

Rolf Ortlep en Maartje Verhoeven, 'The principle of primacy versus the principle of national procedural autonomy', NALL 2012, april-juni, DOI: 10.5553/NALL/.000004

DOI: 10.5553/NALLI.000004

\title{
The principle of primacy versus the principle of national procedural autonomy
}

\author{
Rolf Ortlep en Maartje Verhoeven
}

\section{Introduction}

The case law of the Court of Justice on revoking a national final administrative decision or judgement which is not compliant with EU law can serve as an illustration of the tension which exists between the application of the principle of primacy on the one hand, and the principle of national procedural autonomy on the other. Although the choice of the Court for one of the two principles may seem arbitrary at first glance, it may be possible to provide a system which elucidates this choice to a certain extent. The existence of a system can help as it enhances predictability. It helps to avoid a situation in which there are only intuitive judgments which, because they lack structure, cannot lead to certainty and predictability of the law. In the next section the principles of primacy and national procedural autonomy are discussed and defined, including the principles of equivalence and effectiveness which go hand in hand with the principle of national procedural autonomy. Moreover, the difference between direct and indirect collisions between EU law and national law will be explained. This distinction of German origin is essential for the system provided in this study. In section three several important cases of the Court are discussed which concern the revocation of a national final administrative decision or judgement which is incompatible with EU law. This discussion shows how the Court sometimes takes the principle of primacy as a starting point, whereas other cases are placed in the light of national procedural autonomy. The article is completed by section four in which we will take stock of what has been asserted in the other sections.

\section{Theoretical framework: distinction between direct and indirect collisions}

\subsection{Introduction: principle of primacy versus principle of national procedural autonomy}


The effect and application of EU law in the national legal order are governed by several doctrines, such as direct effect and consistent interpretation. This study, however, will focus on only two of these topics: the principle of primacy and the principle of national procedural autonomy. The primacy of EU law is a rule of conflict: if that law is incompatible with national law, EU law always prevails. This principle was introduced by the Court of Justice in the 1960 s in its wellknown judgement in Costa/ENEL. ${ }^{\mathbf{1}}$ The primacy of EU law is of a general nature and applies in every situation. ${ }^{\mathbf{2}}$ In the literature the primacy of material EU law over material national law has been characterized as 'material primacy', as opposed to 'structural primacy' which concerns cases in which the Court obliges the national court to set aside national procedural rules in specific cases so as to safeguard the effectiveness of EU law. ${ }^{3}$

The principle of primacy does not solve every situation in which EU law in the national legal order is hindered by rules of national law. This applies all the more since the effect of EU substantive law in the national legal order depends to a large extent on national rules of procedural law. In this regard the principle of national procedural autonomy has been developed in Luxembourg case law, which - very briefly - provides that if EU law does not have its own procedural rules, national procedural law is applicable. 4 The principle of national procedural autonomy is limited by two preconditions which have been introduced to guarantee a minimum level of judicial protection in all member states. On the one hand, there is the principle of equivalence, which requires that rules that govern a dispute with an EU law dimension may not be less favourable than those governing similar domestic disputes. On the other hand, the principle of effectiveness, which implies that the exercise of rights conferred by the Union legal order may not be rendered virtually impossible or excessively difficult by rules of national procedural law. 5

The combination of the principles of primacy and national procedural autonomy shows that the relationship between EU law and national law cannot be qualified as one-way communication. Whereas the principle of primacy strictly speaking implies that every provision of national law which impairs the effectiveness of EU law should not be applied, the principle of national procedural autonomy proves that EU law is also dependent on national procedural law to achieve this effectiveness.

\subsection{Direct and indirect collisions}

It is clear that a certain tension exists between the principle of primacy and the principle of national procedural autonomy. That particularly holds true for the above discussed concept of 'structural primacy': the embedded obligation to set aside rules of national procedural law is diametrically opposed to the principle of national procedural autonomy. Hence, it is not surprising that the Court of Justice generally opts for one of these two principles as starting point when answering preliminary questions on collisions between EU law and national law.

The relation between the principle of primacy and the principle of national procedural autonomy has been discussed in the literature for decades, starting with the case of Simmenthal. ${ }^{\mathbf{6}}$ In this case, two different problems actually 
became intertwined. The case started with the material problem that veterinary and public health fees which were levied on imports of beef and veal under Italian law turned out to be incompatible with Community law. ${ }^{7}$ This, however, led to a procedural problem of a constitutional nature, since the lower court in this case was not allowed under national procedural law to decide independently to set aside Italian law which violated Community law: only the constitutional court was allowed to decide this matter. As already known, the Court of Justice gave short shrift to this procedural limitation of the powers of the national court concerned. The Court unambiguously based its judgement on the principle of primacy as the basis for national courts to set aside national law which are incompatible with EU law. This is clearly at odds with the principle of national procedural autonomy, as was developed in the cases Rewe and Comet, in which the Court accepted rules of national law which impeded, to a certain extent, the effect of EU law in the national legal order. 8

The choice of the Court of Justice for one of the two principles as a starting point to solve collisions between EU law and national law may seem rather arbitrary at first glance. It may be possible, however, to explain this choice to a certain extent from the point of view of German doctrine. ${ }^{9}$ To decide which principle should primarily apply, German literature distinguishes between direct and indirect collisions. Although it should be emphasized that the boundary between these two categories may often be blurred, the distinction may be helpful to elucidate the case law of the Court of Justice.

A direct collision concerns a situation in which EU law and national law provide different, incompatible legal regimes for the same factual situation. Compare in this regard Advocate General Jacobs in his Conclusion in the case of Van Schijndel:

\footnotetext{
'In my view, it does not follow from the primacy of Community law that a national court must in all circumstances set aside procedural rules which prevent a question of Community law from being raised at a particular stage in the proceedings. What the primacy of Community law requires in the first place is a general rule that, when a national court is confronted with a conflict between a substantive provision of national law and a substantive provision of Community law, the Community provision should prevail. It is easy to see that, in the absence of such a general rule, Community law would be a dead letter. ${ }^{10}$
}

The distinction between direct and indirect collisions is known in the German federal system for incompatibilities between federal law (Bundesrecht) and the laws of the Länder (Landesrecht), and is based on a hierarchical relation. Although Article 31 of the Grundgesetz provides in very general terms that federal law has priority over the laws of the Länder, the

Bundesverfassungsgericht has consequently held that this rather harsh rule only applies when federal law and the law of the Länder can be applied to the same set of facts, and when this application leads to different incompatible legal consequences. ${ }^{\mathbf{1 1}}$ This approach can also be applied to the correlation between EU law and national law. A direct collision occurs, for example, when an Union obligation meets a national law prohibition, or when EU law grants an individual 
a right which is explicitly excluded under national law. The four freedoms can be important sources for such direct collisions with national law. Indirect collisions concern cases in which rules of national law hinder the effect of EU law in the national legal order, although EU law and national law do not provide different, incompatible legal regimes for the same factual situation. Compare in this regard the above quoted Advocate General Jacobs in the case of Van Schijndel. Indirect collisions often concern national procedural rules, such as time limits in which to initiate judicial proceedings, which can limit the effect of EU law in the national legal order.

The distinction between direct and indirect collisions is - as was already mentioned above - often rather blurred. As a consequence of the development of the principles of equivalence and effectiveness in the case law of the Court of Justice, the principle of national procedural autonomy has become a more balanced doctrine than the more radical principle of primacy. Whereas the principle of primacy has a hierarchical background ${ }^{\mathbf{1 2}}$, the principle of national procedural autonomy leaves discretionary room to balance each situation, depending on the specific facts of the case, since it does not by definition require that national law is set aside in favour of EU law. Again, a parallel can be drawn with German law. With regard to indirect collisions, the more flexible approach of Bundesfreundliche Verhalten applies instead of the more abrasive rule of the priority of federal law which governs direct collisions according to Article 31 of the Grundgesetz. ${ }^{\mathbf{1 3}}$

The distinction between direct and indirect collisions may to a certain extent serve as a system for the choice of the Court of Justice to use either the principle of primacy or the principle of national procedural autonomy as the core principle to decide a case. The concept of direct and indirect collisions, however, cannot explicitly be retraced in the Luxembourg case law. When a direct collision is concerned, meaning that EU law and national law provide different, incompatible legal regimes for the same factual situation, the use of the principle of primacy safeguards the effectiveness of EU law in the national legal order by setting aside the incompatible national law. If this leads to a legal vacuum, EU law can then be applied instead of national law. If that is necessary, EU law itself decides on the legal consequences, and is used as a rule in such situations. In other cases, however, merely setting aside the conflicting national law will suffice. The principle of primacy does not lead to a solution in case of an indirect collision, since no national law is available which can be set aside for an EU law equivalent. For example, when the possibility to exercise Union rights is limited by a time limit in which to initiate judicial proceedings, this leads to the effectiveness of EU law being impeded. However, no EU law exists which can be applied instead of the national time limit. Therefore, such indirect collisions are resolved in the light of the principle of national procedural autonomy. Under this doctrine, EU law sets the boundaries within which national procedural law may be applied by assessing such indirect collisions under the principles of equivalence and effectiveness. In such cases, EU law does not serve as a rule which provides a material outcome for the case, but as a principle, leading to a balance between the effectiveness of EU law, on the one hand, and the background and aim of national law which restricts this effectiveness of EU law on the other. ${ }^{\mathbf{1 4}}$ 


\section{Case law: revoking a national final administrative decision or judgement which is not compliant with EU law}

\section{1 ntroduction}

In the preceding section the distinction between direct and indirect collisions has been discussed. Moreover, it has been introduced as a general rule that the Court of Justice opts for primacy in case of direct collisions, and resolves indirect collisions primarily in the light of national procedural autonomy and the accompanying principles of equivalence and effectiveness. Whereas the principle of primacy has a hierarchical character, the principle of national procedural autonomy leaves more room for assessment, as it does not by definition require that the national rule which hinders the effectiveness of EU law has to be set aside. In this section several important cases are examined, which show the applicability of this general rule to the case law of the Court on revoking a national final administrative decision or judgment which is not compliant with EU law.

\subsection{Ciola}

The first case to be discussed is Ciola. ${ }^{15}$ In this case the Verwaltungsgerichtshof referred two preliminary questions raised in proceedings brought by Ciola against fines imposed on him for exceeding the maximum quota of moorings on the shore of a lake reserved for boats whose owners are resident abroad. This quota was included in an individual administrative decision which was addressed to Ciola, in his capacity as manager of a company leasing land on the shore of the lake, on 9 August 1990. By a decision of 10 July 1996 Ciola was found guilty of renting two moorings to boat owners who were resident abroad, even though the maximum quota had already been exceeded. In his appeal against this decision, the Verwaltungsgerichtshof referred the preliminary question whether the Treaty provisions on the freedom to provide services are to be interpreted as precluding a member state from establishing a maximum quota of moorings which may be rented to boat owners resident abroad. The Court of Justice answered this question in the affirmative. The Court observed that although the restriction on the number of moorings which may be allocated to non-resident boat owners was not based on their nationality, and so may not be regarded as direct discrimination, it did, however, use their place of residence as the distinguishing criterion. The local authorities relied on the need to reserve access to the moorings for local boat owners, as there was a risk of such moorings being monopolised by persons resident in other member states and willing to pay higher rental charges. The Court, however, did not agree with this:

\footnotetext{
'National rules which are not applicable to services without distinction whatever the place of residence of the recipient, and which are therefore discriminatory, are compatible with Community law only if they can be brought within the scope of an express derogation, such as Article 56 of the EC Treaty [...]; however, economic aims cannot constitute grounds of public policy within the meaning of that provision [...]. Consequently, the establishment by a Member State of a maximum quota for moorings which may be rented to boat-owners resident in another Member State is contrary to the principle of freedom to
} 
provide services.'

After answering this first question, the Court addressed the second question, which concerned whether an individual administrative decision, that has become final, must be disregarded when assessing the validity of a fine imposed for a failure to comply with that decision since it is contrary to the Treaty provisions on the freedom to provide services. The Court firstly emphasised:

'that the dispute concerns not the fate of the administrative act itself, in this case the decision of 9 August 1990, but the question whether such an act must be disregarded when assessing the validity of a penalty imposed for failure to comply with an obligation thereunder, because of its incompatibility with the principle of freedom to provide services. ${ }^{16}$

Then the Court concluded that, in observing the principle of primacy, the individual administrative decision concerned should have been disregarded when assessing the validity of a fine imposed, as this decision is contrary to the freedom to provide services.

Several authors have addressed the question why the Court answered the questions in the case of Ciola in the light of the principle of primacy. The common assumption is that this can be explained by the fact that a direct collision was involved, since the Treaty provisions on the freedom to provide services were in a direct conflict with the individual administrative decision of 9 August 1990, in which the maximum quota reserved for foreigners was included. Thus, EU law and the individual administrative decision provided different, incompatible legal regimes for the same factual situation. ${ }^{\mathbf{1 7}}$

\subsection{I-21 \& Arcor}

The case of I-21 \& Arcor $^{\mathbf{1 8}}$ is closely related to the fiercely debated judgement in the case of Kühne \& Heitz ${ }^{\mathbf{1 9}}$. The latter concerned the following preliminary question:

'Under Community law, in particular under the principle of Community solidarity contained in Article $10 \mathrm{EC}$, and in the circumstances described in the grounds of this decision, is an administrative body required to reopen a decision which has become final in order to ensure the full operation of Community law, as it is to be interpreted in the light of a subsequent preliminary ruling?'

The Court ruled that in accordance with the principle of legal certainty, EU law does not require that administrative authorities be placed under an obligation, in principle, to re-examine a national final administrative decision. ${ }^{\mathbf{2 o}}$ However it acknowledged that there could be a limit to this principle in certain cases. The Court determined that, by virtue of Article 4 paragraph 3 of the Treaty on European Union (the principle of loyal cooperation), the administrative authority is obliged to re-examine a national final administrative decision, in order to take account of the interpretation of the relevant provision given in the meantime by the Court, when the following four cumulative conditions are met: 
1. under national law, the administrative authority has the competence to reexamine a final administrative decision;

2. that administrative decision has become final as result of a judgement by the national court ruling in the final instance;

3. that judgement is, in light of a later judgement given by the Court of Justice, based on a misinterpretation of EU law which was given without being referred to the Court for a preliminary judgement under Article 267 of the Treaty on the Functioning of the European Union;

4. the person concerned complained to the administrative authority immediately after becoming aware of that judgement by the Court.

The question as to whether EU law compels a national final administrative decision to be revoked if it does not comply with that law was not answered directly by the Court in the Kühne \& Heitz judgement. The Court confined itself to the observation that the administrative authority will have to determine on the basis of the outcome of the re-examination to what extent it is under an obligation to revoke, without adversely affecting the interests of third parties, a national final administrative decision.

The case of I-21 \& Arcor concerned the preliminary question whether an administrative authority should revoke an administrative decision which is incompatible with EU law and which has become final, although the interested party has not appealed against the decision concerned. Arcor and I-21 were two telecommunications companies, which were granted licences by the administrative authority to provide telecommunications services. To receive such licences, the companies had to pay certain fees. I-21 \& Arcor paid the fees without objection and did not appeal against them within the applicable time limit. Other telecommunications companies, however, appealed against comparable fees, and the Bundesverwaltungsgtericht held in these proceedings that the Telekommunikations-Lizenzgebührenverordnung (TKLGebV), on which the fees were based, was incompatible with the Telekommunikationsgesetz (TKG) and German constitutional law. ${ }^{\mathbf{2 1}}$

Following that judgement, I21 and Arcor sought a repayment of the fees which they had paid. The administrative authority rejected their claims because their fee notices had become final, as they did not appeal in good time. The Verwaltungsgericht dismissed their appeals on the same grounds. Both companies then brought appeal proceedings on before the Bundesverwaltungsgericht. This court then referred the preliminary question as to whether the fees were incompatible with Article 11 (1) of Directive 97/13/EC. That is to say, the objectives of the directive include that of facilitating significantly the entry of new competitors onto the market. 'However', the Bundesverwaltungsgericht continued, 'upholding the fee assessments at issue amounts to a restriction on competition for the undertakings concerned, which are at a disadvantage compared, in particular, with those undertakings which contested the assessments addressed to them within the given time-limits and succeeded in having them annulled'. If this first preliminary question was 
answered in the affirmative, the Bundesverwaltungsgericht then submitted the second preliminary question to the Court of Justice:

\begin{abstract}
'Are Article 10 EC and Article 11 of the Directive [97/13] to be interpreted as meaning that a fee assessment that determines fees within the meaning of Question 1 and which has not been contested, although such a possibility is afforded under national law, must be set aside where that is permissible under national law but not mandatory?'
\end{abstract}

After having ruled that the fees were incompatible with Article 11 (1) of Directive 97/13/EC, the Court then answered the second question. In this regard, Arcor argued that the judgement in Kühne \& Heitz was not relevant, since it concerned an indirect conflict between a rule of national law and a rule of EU law, the first rule thereby preventing the application of the second. According to Arcor, the case in the main proceedings should be regarded as a direct conflict between two rules of substantive law, because EU law (Article 11(1) of Directive 97/13, read in the light of Article $10 \mathrm{EC}$ ) required the fees to be repaid, while the rule of national law prohibited any reimbursement. Arcor took the view that Community law should, in such a case, prevail over conflicting national law. The Court, however, took another approach by observing:

\begin{abstract}
'Contrary to Arcor's claims, the second question does not relate to a conflict between two sets of rules of substantive law on the repayment of fees levied unlawfully. Neither the provisions of Article 11(1) of Directive 97/13 nor those of the TKG and the TKLGebV, as that Law and that Regulation were presented in the file submitted to the Court, deal with such reimbursement.'
\end{abstract}

Hence, the Court observed that no direct collision between national law and EU law was at stake. Therefore the Court answered the second question, taking the case of Kühne \& Heitz as a starting point, in the light of the principle of national procedural autonomy and the principles of equivalence and effectiveness. ${ }^{\mathbf{2 2}}$ With respect to the principle of effectiveness, the Court determined that it is compatible with this principle when national law has laid down reasonable periods within which proceedings must be brought in the interests of legal certainty. After all, these terms are based on the principle of legal certainty, which is recognized and safeguarded in EU law. With respect to the principle of equivalence, the Court is of the opinion that the national courts must determine whether an incompatibility with EU law provides an obligation under national law to revoke a final administrative decision. ${ }^{\mathbf{2 3}}$ On this basis the observation can be made that if national law does not provide a reason for the administrative authority not to revoke a final administrative decision, in other words there is in that respect a national duty to revoke, the administrative authority must do so under EU law if a administrative decision is non-compliant with that law.

\title{
3.3 Lucchini
}

Another case to be discussed is the case of Lucchini ${ }^{\mathbf{2 4}}$, which concerned a very exceptional and uncommon situation, in the sense that the national court pretended to have a power which is exclusively reserved for the Commission: the competence to assess the compatibility of aid with the common market. On 6 
November 1985, the big Italian steel company Lucchini applied for aid on the basis of Italian legislation. By a letter of 20 April 1988, the competent authorities (Ministero dell'Industria, del Commercio e dell'Artigianato (MICA)) informed the Commission of the plan to grant aid to Lucchini. By a letter of 22 June 1988, the Commission requested further information on this aid measure. The competent authorities did not respond to that letter. On 16 November 1988, close to the time limit of 31 December 1988 for the granting of aid, the competent authorities decided to grant the aid to Lucchini, but on a provisional basis. The Commission, however, was unable to assess whether the proposed aid measures were compatible with the common market. Therefore the Commission initiated proceedings against the competent authorities. It informed the authorities to that effect by a letter of 13 January 1989. A communication detailing that procedure was published in the Official Journal of the European Communities of 23 March 1990. By a telexed message on 9 August 1989, the competent authorities forwarded further information on the aid in question. By a letter of 18 October 1989, the Commission notified those authorities that their answer was unsatisfactory in that a number of details were still missing. Then on 20 June 1990 the Commission stated, by way of Decision 90/555/ECSC, that all of the aid intended for Lucchini was incompatible with the common market. The competent authorities were notified of this decision on 20 July 1990 and it was published in the Official Journal of the European Communities of 14 November 1990. Neither Lucchini nor the Italian government challenged that decision.

Prior to the adoption of Decision 90/955 Lucchini had brought proceedings against the competent authorities before the Tribunale civile e penale di Roma (Civil and Criminal Court, Rome) on 6 April 1989 to establish its right to the payment of all of the aid initially claimed. By a judgement of 24 July 1991, that is, subsequent to Decision 90/555, the Tribunale civile e penale di Roma held that Lucchini was entitled to the aid in question and ordered the competent authorities to pay the amounts claimed. That judgement was based entirely on Italian legislation. The parties did not refer to the ECSC Treaty, the third code, the fourth code or Decision 90/555 and neither did that court refer to any of those provisions of its own motion. The competent authorities appealed against this judgement. On 6 May 1994 the Corte d'Appello di Roma dismissed that appeal and upheld the judgement of the Tribunale civile e penale di Roma. Since this judgement in question was not challenged, it became final on 28 February 1995. This, according to article 2909 of the Italian Codice Civile (Civil Code), entitled 'Final judgements', provides as follows: 'Findings made in judgements which have acquired the force of res judicata shall be binding on the parties, their lawful successors and assignees.'

As the aid had still not been disbursed, Lucchini filed an application and on 20 November 1995 the President of the Tribunale civile e penale di Roma ordered the competent authorities to pay the sums due to Lucchini. By a note of 16 September 1996, the Commission expressed its opinion that, by disbursing aid to Lucchini which had already been declared incompatible with the common market in Decision 90/555, the competent authorities had breached Community law and called on those authorities 'to recover the aid in question within 15 days and to inform it, within one month, of the specific measures adopted to comply with that decision'. Therefore, on 20 September 1996 MICA adopted a Decree 
No. 20357 thereby revoking Decree No. 17975 of 8 March 1996 and ordered Lucchini to repay the granted aid. On 16 November 1996 Lucchini challenged Decree No. 20357 before the Tribunale amminstrativo regionale del Lazio. That court granted Lucchini's application by a judgement of 1 April 1999, 'finding that the public authorities' powers to revoke their own invalid acts on the ground that they are unlawful or contain substantive errors were limited in the present case by the finding in a final judgement of the Corte d'appello di Roma that there was a right to be granted aid'. On appeal, however, the Consiglio di Stato decided differently. It found that that there was a conflict between that judgement and Decision 90/555, and it referred two preliminary questions to Luxembourg, essentially asking 'whether Community law precludes the application of a provision of national law, such as Article 2909 of the Italian Civil Code, which seeks to lay down the principle of res judicata in so far as the application of that provision prevents the recovery of State aid granted in breach of Community law which has been found to be incompatible with the common market in a Commission decision which has become final'.

With regard to the principle of res judicata, the Court of Justice observed that according to the national court, Article 2909 of the Italian Civil Code precluded not only the reopening, in a second set of proceedings, of pleas in law which have already been expressly and definitively determined but also precluded the examination of matters which could have been raised in earlier proceedings but were not. In the present case, the principle of res judicata also applied to compatibility with the common market, more specifically the pleas regarding the ECSC Treaty, the third code, the fourth code and Decision 90/555. The Court observed that 'the effect of applying that provision, interpreted in such a manner, in the present case would be to frustrate the application of Community law in so far as it would make it impossible to recover State aid that was granted in breach of Community law'. Since it is settled case law that the assessment of the compatibility of aid measures with the common market falls within the exclusive competence of the Commission, the national court should have refused to apply article 2909 of the Italian Civil Code. Therefore the Court of Justice answered the preliminary questions as follows:

\footnotetext{
'that Community law precludes the application of a provision of national law, such as Article 2909 of the Italian Civil Code, which seeks to lay down the principle of res judicata in so far as the application of that provision prevents the recovery of State aid granted in breach of Community law which has been found to be incompatible with the common market in a decision of the Commission which has become final.'
}

Hence, the case of Lucchini differs from the case of I-21 \& Arcor in the fact that the Court did not depart from the principle of national procedural autonomy and the accompanying principles of equivalence and effectiveness. For a reason which is not specifically mentioned in the judgement, the principle of primacy was applied, although the case of Lucchini did not concern a situation in which EU law and national law provide different, incompatible legal regimes for the same factual situation. Nevertheless, one can say that something comparable to a direct collision is at stake, since the national court pretended to have a power which is exclusively reserved for the Commission: the competence to assess the 
compatibility of aid with the common market. ${ }^{25}$ This infringement of an exclusive competence of the Commission explains the observation of the Court that a procedural rule of national law, that is to say the principle of res judicata, should be left unapplied to allow the recovery of aid granted in breach of EU law which has been found to be incompatible with the common market. This has recently been confirmed in the case of Olimpiclub. ${ }^{\mathbf{2 6}}$ In that case the referring court wished to ascertain whether, in the light of the Lucchini judgement, EU law requires it to disapply a national rule laying down the principle of res judicata, which confers finality on a judgement drawn up by another court in a case on the same subject, if to do so would enable it to find in a dispute relating to the payment of value added tax that the transaction concerned was actually designed solely to obtain a tax advantage and thus constituted abusive practice. The Court of Justice ruled that the reason that it did not apply the principle of national procedural autonomy and the accompanying principles of equivalence and effectiveness in the case of Lucchini, was because it 'concerned a highly specific situation, in which the matters at issue were principles governing the division of powers between the member states and the Community in the area of State aid, the Commission of the European Communities having exclusive competence to assess the compatibility with the common market of a national State aid measure'. ${ }^{27}$

\section{Conclusion}

Although the boundary line may sometimes be blurred and the approach of the Court of Justice in a specific case will - to a certain extent - always remain unpredictable, the distinction between direct and indirect collisions may be helpful to understand the choice of the Court for applying the principle of primacy or the principle of national procedural autonomy as a starting point to solve collisions between EU law and national law. Although the primacy of EU law over national law is a generally applicable principle, its use only leads to a solution when a direct collision is concerned. That is to say, a situation in which EU law and national law provide different, incompatible legal regimes for the same factual situation. With regard to indirect collisions, that is to say cases in which rules of national law, often of a procedural character, hinder the effect of EU law in the national legal order, the principle of primacy does not lead to a solution as there is no incompatible national law which can be set aside in favour of the hampered EU law. The case law on revoking a national final administrative decision or judgement which is not compliant with EU law exemplifies this system. The case of Ciola concerned an individual administrative decision which had become final and which limited the number of moorings reserved for foreigners, thus directly violating the Treaty provisions on freedom to provide services. In other words, the application of the principle of primacy solves a situation in which EU law and national law provide different, incompatible legal regimes for the same factual situation. In the case of I-21 \& Arcor, the Court adopted the approach of the principle of national procedural autonomy as it observed that no direct collision between national law and EU law was at stake. Finally, the case of Lucchini showed that the principle of primacy may also solve situations which resemble a direct collision, when a national court pretends to have a competence which clearly and undisputedly is reserved for the Commission. 


\section{Noten}

1 Case 6/64, Costa/Enel, [1964] ECR 1203.

2 See extensively B. de Witte, 'Direct Effect, Primacy, and the Nature of the Legal Order', in: P. Craig \& G. de Búrca (eds.), The Evolution of EU Law, Oxford: OUP 2011, p. 323-362; M. Claes, The national courts' mandate in the European constitution, Oxford: Hart Publishing 2006, p. 97 ff including references.

3 See M. Claes 2006, p. 100 including references.

4 Case 33/76, Rewe, [1976] ECR 1989; case 45/76, Comet, [1976] ECR 2043.

5 See A. Adinolfi, "The "Procedural Autonomy" of Member States and the Constraints Stemming from the ECJ's Case Law: Is Judicial Activism Still Necessary?', in: H.-W. Micklitz \& B. de Witte (eds.), The European Court of Justice and the Autonomy of the Member States, Cambridge: Intersentia 2012, p. 281-303; S. Prechal \& R.J.G.M. Widdershoven, 'Effectiveness or Effective Judicial Protection: A Poorly Articulated Relationship', in: T. Baumé et al. (eds.), Today's Multi-layered Legal Order: Current Issues and Perspectives, Zutphen: Paris 2011, p. 283-296 including references.

6 Case 106/77, Simmenthal, [1978] ECR 629.

7 Case 35/76, Simmenthal, [1975] ECR 1871.

8 Case 33/76, Rewe, [1976] ECR 1989; case 45/76, Comet, [1976] ECR 2043.

9 See F.C. Mayer, 'Europäisches Verwaltungsrecht und nationales Verfassungsrecht', in: J.P. Terhechte (Hrsg.), Verwaltungsrecht der Europäischen Union, Baden-Baden: Nomos 2011, p. 307-329; J.M. Baumann, Die Rechtsprechung des EuGH zum Vorrang von Gemeinschaftsrecht vor mitgliedstaatlichen Verwaltungsakten und Gerichtsurteilen, Frankfurt am Main: Peter Lang 2010, p. 10 ff; H. Juntunen, Die Einwirkungen des Gemeinschaftsrechts auf die Bestandskraft von Verwaltungsakten und die Rechtskraft von Gerichtsurteilen, Berlin: WVB 2009, p. 82 ff; A. Saßenroth, Die Bestandskraft deutscher Steuerbescheide im Licht der Rechtsprechung des EuGH, Berlin: Lit 2009, p. 64 ff; M. Niedobitek, 'Der Vorrang des Unionsrechts', in: M. Niedobitek \& J. Zemánek (eds.), Continuing the European Constitutional Debate: German and Czech Contributions from a Legal Perspektive, Berlin: Duncker \& Humblot 2008, p. 63-104 including references. Further H. Jarass \& S. Beljin, 'Die Bedeutung von Vorrang und Durchführung des EG-Rechts für die nationale Rechtsetzung und Rechtsanwendung', NVwZ 2004, p. 1-11; M. Niedobitek, 'Kollisionen zwischen EG-recht und nationalem Recht', VerwArchiv 2001, p. 58-80 including references.

10 A-G Jacobs in his conclusion in joined cases C-430/93 \& C-431/93, Van Schijndel, [1995] ECR I-4705. Compare also his conclusion in case C-312/93, Peterbroeck, [1995] ECR I-4599. 
11 See A. Peters, 'Rechtsordnungen und Konstitutionalisierung: zur Neubestimmung der Verhältnisse', ZÖR 2010, p. 3-63 including references. Further K. Engelbrecht, Die Kollisionsregel im föderalen Ordnungsverbund, Tübingen: Mohr Siebeck 2010; A. Schmitt, Der bundesstaatliche Rahmen für die Landesverfassungen, Hamburg: Kovac 2009 including references.

12 For example Case 106/77, Simmenthal, [1978] ECR 629. See M. Avbelj, 'Supremacy or Primacy of EU Law - (Why) Does it Matter?', ELJ 2011, p. 744763; R. Barents, 'The Precedence of EU Law from the Perspective of Constitutional Pluralism', EuConst 2009, p. 421-446; K. Lenaerts \& T. Corthaut, 'Of Birds and Hedges: the Role of Primacy in Invoking Norms of EU Law', ELRev 2006, p. 287-315 including references.

13 See the German comments on the Grundgesetz; for example H. Hofmann in: Schmidt-Bleibtreu/Klein, Kommentar zum Grundgesetz, München:

Luchterhand 2004, art. 20, rn. 13 ff including references.

14 See H. Juntunen 2009, p. 83 ff including references.

15 Case 224/97, Ciola, [1999] ECR I-2517.

16 See J.M. Baumann 2010, p. $121 \mathrm{ff}$ and p. 130; H. Juntunen 2009, p. 201; A. Saßenroth 2009, p. 94-95; C.F. Germelmann, Die Rechtskraft von Gerichtsentscheidungen in der Europäischen Union. Eine Untersuchung vor dem Hintergrund der deutschen, französischen und englischen Rechtskraftlehren, Tübingen: Mohr Siebeck 2009, p. 265 including references.

17 See J.M. Baumann 2010, p. 121 ff; H. Juntunen 2009, p. 200 ff; A. Saßenroth 2009, p. 94; W. Weiß, 'Bestandskraft nationaler belastender verwaltungsakte und EG-Recht', DÖV 2008, p. 477-487; C. Kremer, 'Gemeinschaftsrechtliche Grenzen der Rechtskraft', Europarecht 2007, p. 470-493; C. Säcker, Der Einfluss der sektorspezifischen Regulierung auf die Anwendung des deutschen und gemeinschaftlichen Kartellrechts, Münster: Lit Verlag 2006, p. 207-208; M. Potacs, 'Gemeinschaftsrecht und Bestandskraft staatlicher Verwaltungsakte', in: J. Bröhmer (Hrsg.), Internationale Gemeinschaft und Menschenrechte, Köln: Heymann 2005, p. 729-741 including references.

18 Joined cases C-392/04 \& C-422/04, I-21 and Arcor, [2006] ECR I-8559.

19 Case C-453/oo, Kühne \& Heitz, [2004] ECR I-837.

20 In the case of Kapferer, C-234/04, [2006], ECR I-2585, the Court ruled that 'Community law does not require a national court to disapply domestic rules of procedure conferring finality on a decision, even if to do so would enable it to remedy an infringement of Community law by the decision at issue'.

21 Compare A-G Colomer in his conclusion in the case of I21 and Arcor.

22 See C.F. Germelmann 2009, p. 267 ff; H. Juntunen 2009, p. 82, p. 167, p. 181 and p. 191; A. Saßenroth 2009, p. 67-68 including references. 
23 In the case of Kapferer, C-234/04, [2006], ECR I-2585, the Court was unable to determine the extent to which EU law - within the framework of the principle of national procedural autonomy and the principles (limits) of equivalence and effectiveness - compels a national final judgement to be revoked if it does not comply with that law, because 'compliance with the limits of the power of the Member States in procedural matters has not been called into question in the dispute in the main proceedings as regards appeal proceedings'.

24 Case C-119/o5, Lucchini, [2007] ECR I-6199.

25 See C.F. Germelmann 2009, p. 271-273 and p. 284-285; X. Groussot \& H.H. Lidgard, 'Are there General Principles of Community Law Affecting Private Law?', in: U. Bernitz, J. Nergelius \& C. Cardner (eds.), General Principles of EC Law in a Process of Development, Alphen aan den Rijn: Kluwer Law International 2008, p. 155-175; X. Groussot \& T. Minssen, 'Res judicata in the Court of Justice case-law: Balancing legal certainty with legality', EuConst 2007, p. 385-417; C.F. Germelmann, 'Neue Wege in der Rechtsprechung des EuGH zu nationalen Rechtskraftregeln?', EWS 2007, p. 392-398 including references.

26 Case C-2/o8, Olimpiclub, [2009] ECR I-7501. See A. Adinolfi 2012, p. 288 ff including references.

27 Compare also case C-40/o8, Asturcom, [2009] ECR I-9579.

(C) Boom Juridische uitgevers 
